\title{
EPIDEMIOLOGICAL CHARACTERISTICS OF COMMUNITY-ACQUIRED PNEUMONIA DURING THE COVID-19 EPIDEMIC IN THE RUSSIAN FEDERATION
}

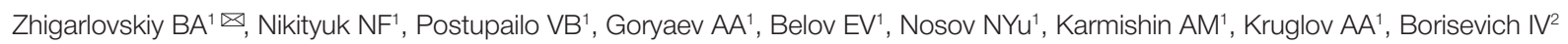

${ }^{1}$ Federal state budgetary institution "Center for Strategic Planning and Management of Medical and Biological Health Risks" of the Federal Medical-Biological Agency (Centre for Strategic Planning of FMBA of Russia), Russia, Moscow

2 Federal Medical-Biological Agency, Russia, Moscow

COVID-19 belongs to the group of acute respiratory infections and it is often complicated with pneumonia. This study aimed to investigate manifestations of community-acquired pneumonia (CAP) epidemic process during the COVID-19 epidemic in the Russian Federation. We analyzed the official statistical data reporting the incidence of CAP in the Russian Federation in 2013-2020 and incidence of COVID-19 as registered in March-July 2020. The mean average annual CAP incidence rate that we calculated and the 2020 CAP incidence prediction allowed assessing the relationship between CAP and COVID-19. It is shown that the long-term dynamics of the incidence of CAP in the Russian Federation is characterized by a pronounced upward trend with an average annual growth rate of $6.4 \%$. The share of adult population among the CAP cases is the largest; on average, it is $64.7 \%(95 \% \mathrm{Cl}[63.1 ; 66.3])$. In 2020, against the background of SARS-CoV-2 circulation, the discrepancy between the actual incidence of CAP and the predicted figures reached and exceeded 558\% (in July 2020). As the COVID-19 epidemic developed, the incidence of CAP was registered to increase. There was established a direct and significant correlation between the incidence of CAP and COVID-19 $\left(r_{x y}=0.932 ; p<0.01\right)$.

Keywords: community-acquired pneumonia, epidemiological characteristics, COVID-19, SARS-CoV-2, correlation, coronavirus, coronavirus disease

Author contribution: all authors significantly contributed to the research methodology design, data collection, analysis and interpretation. All authors participated in the manuscript drafting and editing processes and preparation of the final version of the article.

Correspondence should be addressed: Bronislav Andreevich Zhigarlovskiy

Shchukinskaya, 5, str. 6, Moscow, 123182; bzhigarlovskiy@cspmz.ru

Received: 22.12.2020 Accepted: 27.01.2021 Published online: 16.02.2021

DOI: $10.47183 /$ mes.2021.004

\section{ПРОЯВЛЕНИЯ ЭПИДЕМИЧЕСКОГО ПРОЦЕССА ВНЕБОЛЬНИЧНЫХ ПНЕВМОНИЙ В ПЕРИОД ЭПИДЕМИИ COVID-19 НА ТЕРРИТОРИИ РОССИЙСКОЙ ФЕДЕРАЦИИ}

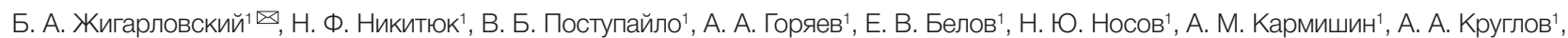
И. В. Борисевич²

${ }^{1}$ Центр стратегического планирования и управления медико-биологическими рисками здоровью Федерального медико-биологического агентства, Москва, Россия

2 Федеральное медико-биологическое агентство, Россия, Москва

COVID-19 относится к группе острых респираторных инфекций и зачастую осложняется развитием пневмоний. Целью исследования было изучить проявления эпидемического процесса внебольничных пневмоний (ВП) в период эпидемии COVID-19 на территории Российской Федерации. Проводили анализ официальных статистических форм по заболеваемости ВП в РФ за 2013-2020 гг. и данных о заболеваемости COVID-19 за март-июль 2020 г. Рассчитывали среднегодовые показатели заболеваемости ВП, прогностические уровни на 2020 г. и оценивали взаимосвязь заболеваемости ВП и COVID-19. Показано, что многолетнюю динамику заболеваемости ВП населения РФ характеризует выраженная тенденция к повышению со среднегодовым темпом прироста 6,4\%. Наибольшую долю среди заболевших ВП составляет взрослое население в среднем 64,7\% (95\% ДИ [63,1; 66,3]). В 2020 г. на фоне циркуляции SARS-CoV-2 расхождение фактической заболеваемости ВП от прогнозируемой достигало более $558 \%$ (июль 2020 г.). В условиях развития эпидемии COVID-19 было отмечено повышение заболеваемости ВП. Установлена прямая статистически значимая корреляционная связь между заболеваемостью ВП и COVID-19 $\left(r_{\text {xу }}=0,932 ; p<0,01\right)$.

Ключевые слова: внебольничная пневмония, эпидемиологическая характеристика, COVID-19, SARS-CoV-2, корреляция, коронавирус, коронавирусная инфекция

Вклад авторов: все авторы внесли значимый вклад в разработку методики исследования, получение, анализ и интерпретацию данных. Участвовали в подготовке черновика рукописи и ее редактировании, а также в подготовке финального варианта статьи.

$\searrow$ Для корреспонденции: Бронислав Андреевич Жигарловский ул. Щукинская, д. 5, стр. 6, г. Москва, 123182; bzhigarlovskiy@cspmz.ru

Статья получена: 22.12.2020 Статья принята к печати: 27.01.2021 Опубликована онлайн: 16.02.2021

DOI: $10.47183 /$ mes.2021.004

In December 2019, an outbreak of a new respiratory infection was registered in the Chinese city of Wuhan. This infection was accompanied with an increase in the number of patients with pneumonia of unknown etiology. In a relatively short time, the outbreak became a pandemic. The patients exhibited symptoms of an upper respiratory tract infection: sore throat and rhinorrhea, as well as fever, cough, myalgia, shortness of breath, and signs of pneumonia visible on the chest $\mathrm{x}$-ray pictures. Subsequently, it was established that the causative agent of this infection is a new coronavirus, dubbed SARS-CoV-2. The disease that followed was named COVID-19 [1].
As part of a large-scale study conducted in China, the researchers analyzed data describing the course of the disease in 1099 patients with laboratory-confirmed COVID-19 diagnosis. It was established that the majority of hospitalized patients (91.1\%) were diagnosed with pneumonia [2].

In Russia, the first cases of COVID-19 were diagnosed in February 2020. The infected were citizens of the PRC. By early July, the number cases registered and reported has grown to over 650,000 [3-5].

Every year, there are 1.5 million community-acquired pneumonia (CAP) cases registered in Russia, which translates into approximately 390 cases per 100,000 people. 
The average mortality rate is up to $5 \%$ of the number of cases [6].

According to epidemiological studies carried out in a number of foreign countries, the incidence rate of CAP varies depending on age, reaching the minimum in young and middleaged populations (1-11.6 cases per 1000 people). In children under 17, the incidence of CAP ranges from 2 to 15 cases per 1000 people in different years. The group most susceptible to CAP is comprised of the elderly people, over 70 years of age: annually 25-44 cases per 1000 people $[7,8]$.

The situation with CAP incidence in USA is also alarming. There are 5-6 million CAP cases registered there annually, with 1.5 million of them requiring inpatient treatment $[9,10]$.

In recent years, the number of deaths from pneumonia has increased. According to the American Thoracic Society, for 18-20\% of the total number of CAP patients the disease ends in death [11].

The outcome of CAP depends on a number of various risk factors, which, when exposed to, increase the likelihood of death. Of great importance are the patient's age, clinical form and severity of the disease, comorbidities [12].

According to the research data, young and middle-aged patients with mild and moderate clinical forms of CAP and without concomitant pathologies recover well; for these age groups, the mortality rate is $1-3 \%$ [13].

In elderly patients that endure CAP in its severe form and have upper respiratory tract comorbidities, cancers, cardiological diseases, alcoholism in the background, the mortality rate rises up to 15-58\% [14].

At the same time, it has been shown that CAP becomes more common when influenza and acute respiratory viral infections (ARVI) are on the rise, and the highest mortality from CAP is recorded 1-2 months after the peaks of influenza and ARVI epidemics [15].

Since COVID-19 is also an acute respiratory infection, it will be relevant to study epidemic features of CAP during the COVID-19 epidemic.

This study aimed to investigate manifestations of community-acquired pneumonia (CAP) epidemic process during the COVID-19 epidemic in the Russian Federation.

\section{METHODS}

The long-term dynamics of CAP incidence in the Russian Federation was analyzed in the context of a descriptive retrospective epidemiological study relying on the data collected with the Federal Statistical Observation Form \#2 "Information on Infectious and Parasitic Diseases" (hereinafter — Form \#2) in 2013-2018.

Inside a year, the CAP incidence dynamics analysis and the calculation of the seasonal incidence level in Russia relied on the data collected with Form \#1 in 2013-2019.

The 2019 incidence rate analysis made use of the data collected with the Federal Statistical Observation Form \#1 "Information on Infectious and Parasitic Diseases (monthly)" that covered January-December 2019 (hereinafter — Form \#1). We established the yearly CAP incidence level and calculated the prognostic incidence rate for the coming period.

To analyze the incidence of COVID-19, we relied on the official information on the number of cases registered in the Russian Federation [16]. Form \#1 data for January-July 2020 allowed assessing the incidence of CAP against the background of the COVID-19 epidemic.

To assess the differences in relative indicators, we calculated the $95 \% \mathrm{Cl}(m \pm 2.45 \times$ SEM, where $m$ is the mean incidence over the period, SEM is the standard error of the mean). The differences were considered statistically significant at $p<0.05$. The least square method enabled calculation of the long-term CAP incidence dynamics, which was assessed by the average annual increase/decrease rate. We compared the value obtained with the gradation suggested by V.D. Belyakov [17]. To assess the relationship between the incidence of CAP and COVID-19, we established the Pearson correlation coefficient $\left(r_{x y}\right)$. The relationship was considered statistically significant at $p<0.05$, with Chaddock's scale used to identify the strength of the relationship.

Microsoft Excel 2013 (Microsoft; USA) application was used to process and analyze the data obtained.

\section{RESULTS}

The analysis of structure of infectious and parasitic disease cases registered in 2013-2019 revealed that in Russia, acute infections of the upper respiratory tract of multiple and unspecified localization (ICD-10 code: J06) (ARI) are the most common diseases, with their share averaging at $90.7 \%$ within the period. The share of CAP is $1.7 \%$, and influenza accounts for $0.6 \%$ of cases (Fig. 1).

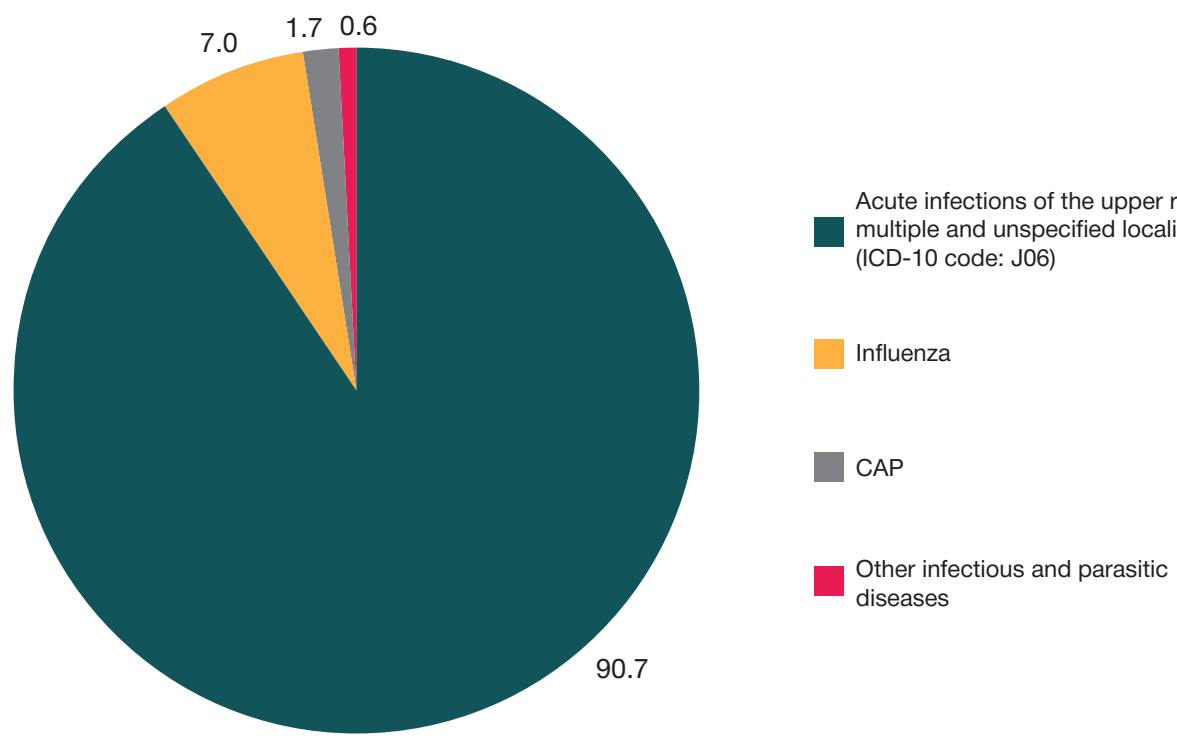

Fig. 1. Structure of infectious and parasitic diseases in the Russian Federation, mean, in \%, years 2013-2019 
Table 1. CAP incidence rates in the Russian Federation, years 2013-2019

\begin{tabular}{|c|c|c|c|c|c|c|}
\hline \multirow{2}{*}{$\begin{array}{c}\text { Observation } \\
\text { year }\end{array}$} & \multirow{2}{*}{$\begin{array}{l}\text { Total cases } \\
\text { (abs. terms) }\end{array}$} & \multirow{2}{*}{$\begin{array}{l}\text { Incidence per } 100 \\
\text { thousand people }\end{array}$} & \multicolumn{2}{|c|}{ Including children under 17} & \multicolumn{2}{|c|}{ Including children under 14} \\
\hline & & & $\begin{array}{l}\text { Total cases } \\
\text { (abs. terms) }\end{array}$ & $\begin{array}{l}\text { Incidence per } 100 \\
\text { thousand people }\end{array}$ & $\begin{array}{l}\text { Total cases } \\
\text { (abs. terms) }\end{array}$ & $\begin{array}{l}\text { Incidence per } 100 \\
\text { thousand people }\end{array}$ \\
\hline 2013 & 557,346 & 389.2 & 190,720 & 713.9 & 176,146 & 782.4 \\
\hline 2014 & 509,765 & 349.5 & 182,014 & 660.6 & 172,278 & 734.4 \\
\hline 2015 & 492,458 & 337.1 & 165,155 & 588.5 & 157,159 & 653.1 \\
\hline 2016 & 612,012 & 418 & 197,594 & 688.8 & 187,549 & 759.7 \\
\hline 2017 & 604,771 & 412.3 & 215,980 & 737.3 & 201,443 & 797.3 \\
\hline 2018 & 721,987 & 491.7 & 270,495 & 908.4 & 247,113 & 962.2 \\
\hline 2019 & 760,074 & 517.2 & 291,064 & 976.8 & 265,861 & 1034.6 \\
\hline \multirow[b]{2}{*}{$\begin{array}{l}\text { Long-time } \\
\text { average annual }\end{array}$} & \multirow[b]{2}{*}{$\begin{array}{c}608,345(95 \% \mathrm{Cl} \\
[514,432 ; 702,257])\end{array}$} & 416.4 & \multirow{2}{*}{$\begin{array}{c}216,146(95 \% \mathrm{Cl} \\
[172,511 ; 259,781])\end{array}$} & 753.4 & \multirow[b]{2}{*}{$\begin{array}{c}201,078(95 \% \mathrm{Cl} \\
[163,503 ; 238,654])\end{array}$} & 817.7 \\
\hline & & $\begin{array}{c}(95 \% \mathrm{Cl} \\
[353.9 ; 479])\end{array}$ & & $\begin{array}{c}(95 \% \mathrm{Cl} \\
[624.9 ; 882.1])\end{array}$ & & $\begin{array}{c}(95 \% \mathrm{Cl} \\
[694 ; 941.3])\end{array}$ \\
\hline
\end{tabular}

The upward trend with the annual growth rate (AGR) of $6.4 \%$ was characteristic for CAP incidence in Russia in 2013-2019. Every year, there are 492-760 thousand new cases of the disease registered among the overall country's population, including 165-291 thousand cases in children under 17.

Children under 14 and up to 17, inclusively, have also exhibited a pronounced CAP incidence upward trend, with the AGR of $6.8 \%$ and $5.9 \%$, respectively.

The 7-year analysis of CAP incidence in the Russian Federation showed that, on average, 608345 cases of CAP are registered annually among the adult population (the incidence rate is 416.4 per 100 thousand population), of which 216146 cases are in children under 17 years of age inclusively (753.4 per 100 thousand), including 201,078 cases (817.7 per 100 thousand of the population) in children under 14 years of age (Table 1).

In general, the CAP incidence in 2019 was 5.3\% greater than in 2018. For children, the trend is the same, with the growth at $7.6 \%$.

In the Russian Federation, within the period analyzed $64.7 \%(95 \% \mathrm{Cl}[63.1 ; 66.3])$ of the CAP cases were registered among adults, 2.4\% - among children aged 15-17 (95\% Cl [1.9; 2.9]) and $32.9 \%$ - in children under 14 inclusively $(95 \% \mathrm{Cl}$ [31.8; 34.1]).
Analysis of the long-term dynamics of CAP incidence reveals a steady growth of the level thereof (approximation confidence factor $R^{2}=0.72$ ), with additional 26.5 cases per 100 thousand people registered every year. These indicators considered, the estimated 2020 CAP incidence rate in the overall population is 522.6 cases per 100 thousand people (95\% Cl [388.2; 657.1]) (Fig. 2).

Analyzing the yearly CAP incidence data of 2013-2019, we established seasonal character of the disease: about $70 \%$ of all the cases registered annually belong to autumn and winter periods.

The level of year-round and seasonal incidence of CAP in the overall population of the Russian Federation within the investigated period is 39.2 and 43.8 cases per 100 thousand people, respectively (Fig. 3). The obtained indicators allow determining when the incidence starts and ends rising, as well as to establish favorable and unfavorable periods.

Thus, in 2019, within the periods from January to Apri and from October to December population of the Russian Federation contracted CAP at a greater scale than on average throughout the year. As for the seasonal incidence levels, they are exceeded in January-March and October-December periods.

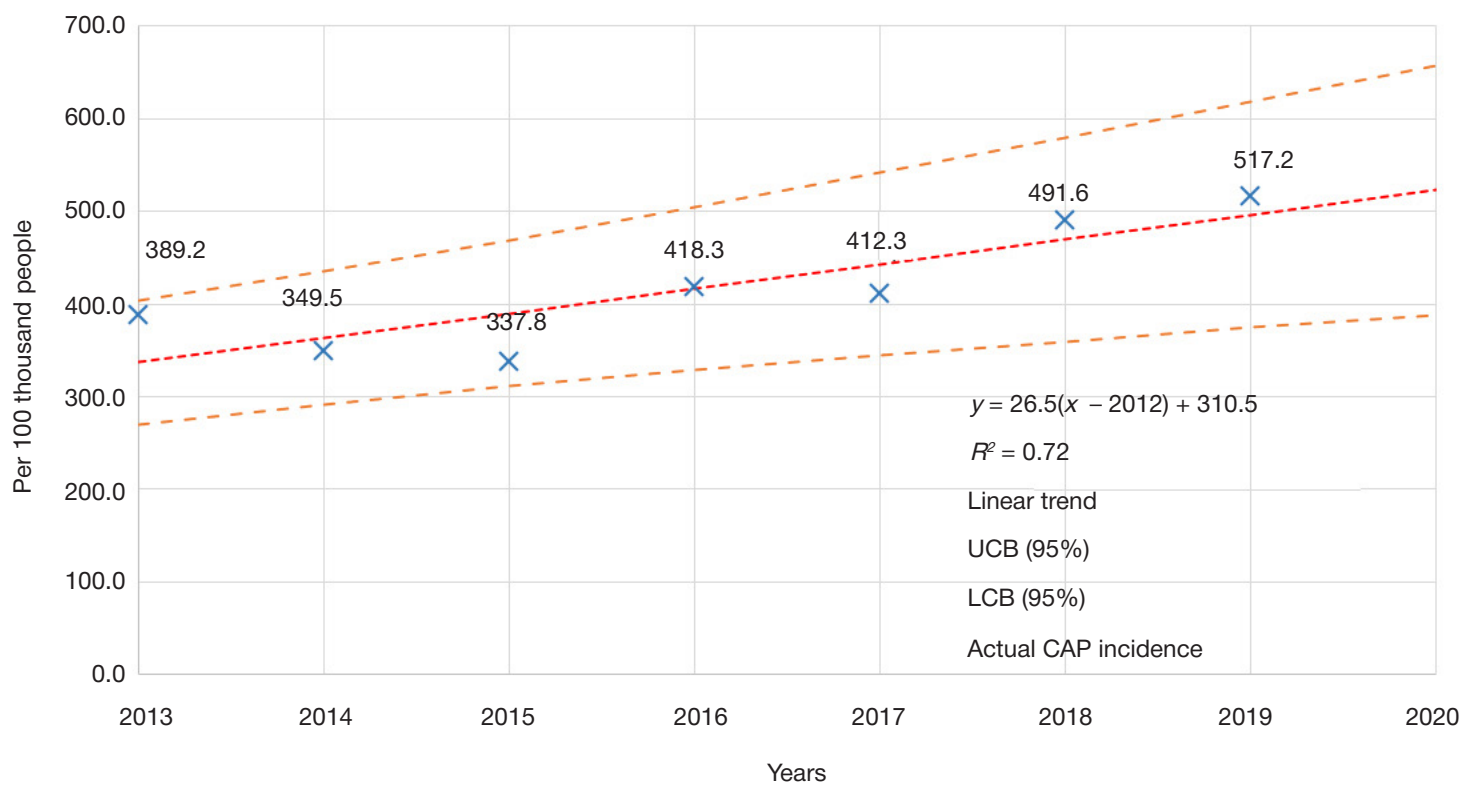

Fig. 2. Long-term dynamics of the incidence of CAP in the total population of the Russian Federation, per 100 thousand people, years $2013-2019$ 


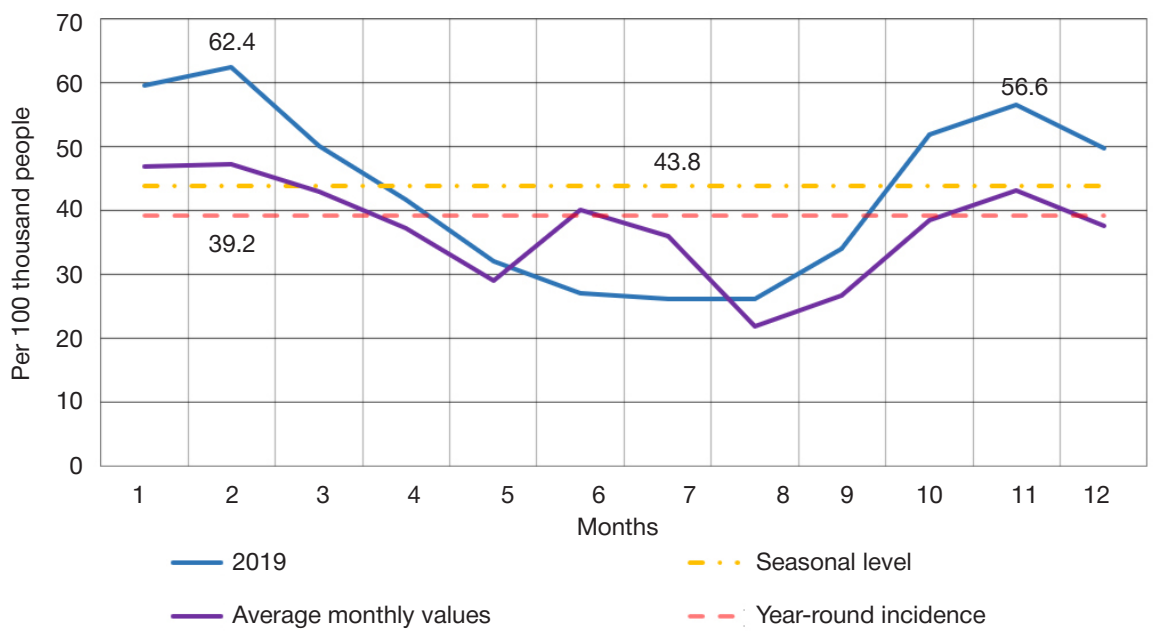

Fig. 3. Intra-annual dynamics of the incidence of CAP in the total population of the Russian Federation, per 100 thousand people

The analysis of seasonal manifestations revealed a more pronounced epidemiological stress peculiar to the first half of 2019 compared to the second part of the year.

In 2019, CAP incidence peaked in February, when it amounted to 62.4 per 100 thousand people, exceeding the year-round and seasonal levels by $71 \%$ and $42.5 \%$, respectively.

Based on the actual CAP incidence recorded in 20132019, we calculated the prognostic level of monthly incidence for 2020. The lowest 2020 CAP incidence level in Russia (overall population) is forecast for July and August, with the figures being 20.7 and 21 cases per 100 thousand people, respectively. The peak is expected in in January, February and November of the year, with 46.2 and 40.0 cases per 100 thousand people, respectively.

The 2020 incidence forecast should approach the average rate recorded in the 2013-2019 period; the expected match value is $89.9 \%( \pm 9.6 \% ; p<0.05)$.

At the same time, against the background of SARS-CoV-2, 2020 saw a statistically significant $(p<0.05)$ discrepancy between the actual CAP incidence and the predicted level: in February, the gap reached $27.9 \%$, and in July it has grown to $558.5 \%$ (Fig. 4).

With the epidemic spread of the new coronavirus infection (COVID-19) in Russia, from the scientific and practical viewpoints it is particularly interesting to study the results of the analysis comparing January-July 2020 CAP incidence data to the figures recorded during January-July 2019, when the COVID-19 epidemic was on the rise.

Within the period from January to July 2020, the incidence of CAP in the population of the Russian Federation increased by $125.2 \%$ compared to the same period of 2019 , and reached 673.9 cases per 100 thousand people (Table 2 ).

Considered on the level of Federal Districts (FD), the greatest CAP incidence growth during the period analyzed (January-July), compared to the same period of the previous year, was registered in the Central FD (+282.4\%) and the North Caucasian FD (+254\%). In absolute terms, it is 278089 and 41203 cases, respectively.

At the same time, in the Far Eastern FD the CAP incidence dropped insignificantly by $-4.1 \%$.

From March to May 2020, the incidence of COVID-19 on the territory of the Russian Federation was growing steadily. In January and February, there were no COVID-19 cases registered. The most significant increase was recorded in May 2020, when the incidence grew 2.7 times compared to April 2020 (from 75.7 cases to 203.6 cases per 100 thousand people, respectively).

It should be noted that the analysis of relationship between CAP and COVID-19 incidence in the population of the Russian Federation within the period from January to July 2020 allowed us to establish a direct, very high and statistically significant link between these indicators (Pearson's coefficient $r_{x y}=0.932$; $t=5.731 ; p<0,01)$

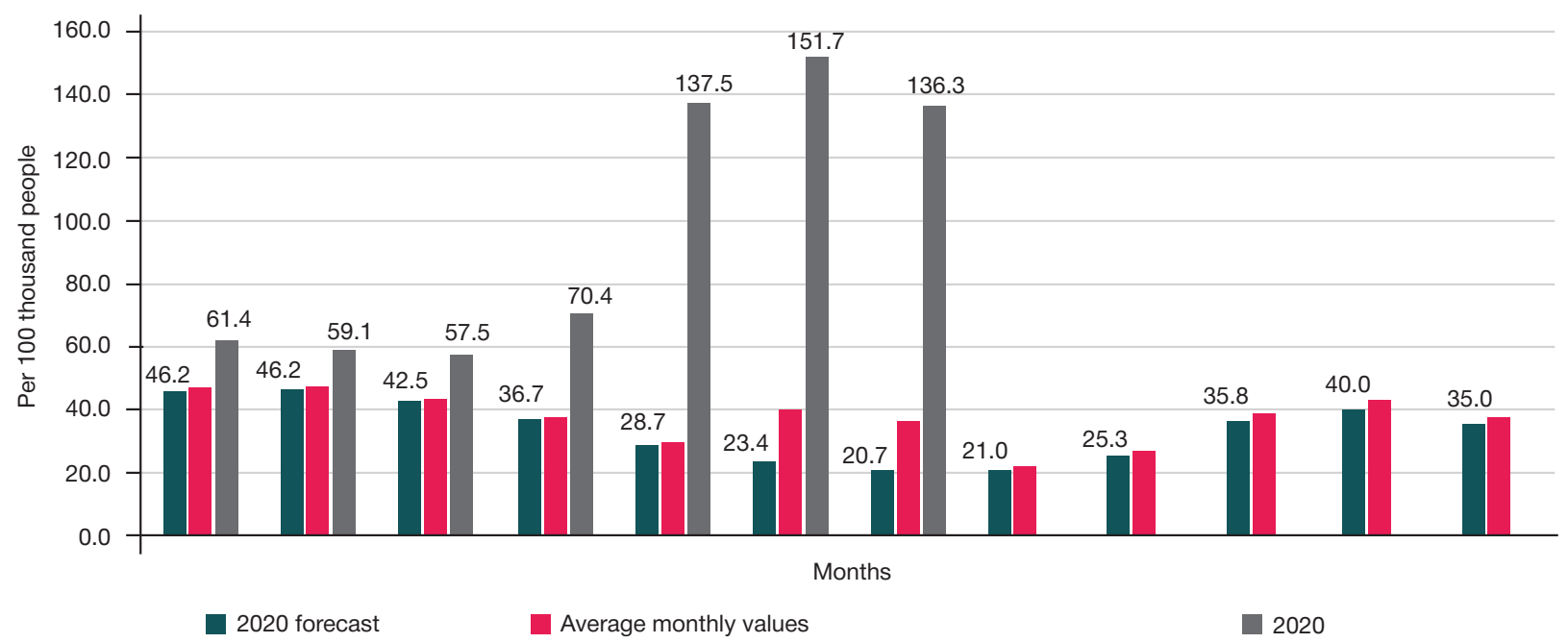

Fig. 4. Predicted and actual intra-annual incidence of CAP in the population of the Russian Federation, per 100 thousand people 
Table 2. CAP incidence in the population of the Russian Federation by federal districts, per 100 thousand people, January-July 2019 and 2020 , with COVID-19 epidemic in the background

\begin{tabular}{|l|c|c|c|}
\hline \multicolumn{1}{|c|}{ Territory } & CAP in 2020 & CAP in 2019 & Increase/decrease \\
\hline Russian Federation & 673.9 & 299.2 & $125.2 \%$ \\
\hline Central FD & 956.4 & 250.1 & $282.4 \%$ \\
\hline Northwestern FD & 666.5 & 262.4 & $154.0 \%$ \\
\hline Southern FD & 355.8 & 221 & $61.0 \%$ \\
\hline North Caucasian FD & 582.2 & 164.5 & $254.0 \%$ \\
\hline Volga FD & 669.1 & 333.9 & 1026.9 \\
\hline Ural RD & 583.7 & 406.2 & 354.8 \\
\hline Siberian FD & 488.2 & 327 & 34.4 \\
\hline Far Eastern FD & 622.5 & 649.1 & 49.3 \\
\hline
\end{tabular}

\section{DISCUSSION}

The results of the study allowed investigating manifestations of the CAP epidemic process before and during the COVID-19 epidemic. Given that COVID-19 is a new infectious disease, most studies cover clinical manifestations of this infection $[18,19]$.

\section{CONCLUSION}

1. The long-term dynamics of CAP incidence in Russia shows a pronounced upward trend, which is seen in both the overall population ( $\mathrm{AGR}=6.4 \%$ ) and among children
$(A G R=6.8 \%) .2$. Within the period analyzed, the majority of cases were adults (on average, $64.7 \%$ of the registered CAP cases). 3. In the period from 2013 to 2019 , the year-round CAP incidence rate in the overall population of Russia is 39.2 cases per 100 thousand people, and the seasonal level is 43.8 cases per 100 thousand people. 4. In 2020, against the background of SARS-CoV-2 circulation, the discrepancy between the actual incidence of CAP and the predicted incidence value reached over 558\% (July 2020), which indicates an increase in the incidence of CAP during the COVID-19 epidemic. 5. A direct, statistically significant correlation between the incidence of CAP and COVID-19 reveals the relationship between the development of the epidemic process of these infections.

\section{References}

1. Gorbalenya AE, Baker SC, et al. Coronaviridae Study Group of the International Committee on Taxonomy of Viruses. The species Severe acute respiratory syndrome-related coronavirus: classifying 2019-nCoV and naming it SARS-CoV-2. Nat Microbiol. 2020; 5: 536-44.

2. Guan WJ, Ni ZY, HuY, et. al. Clinical Characteristics of Coronavirus Disease 2019 in China. N Engl J Med. 2020 Apr 30; 382 (18): 1708-20. DOI: 10.1056/NEJMoa2002032. Epub 2020 Feb 28. PMID: 32109013; PMCID: PMC7092819.

3. Ashabova LM, Sabirov LF, Untilov GV, Gadzhieva LA. COVID-19 $\checkmark$ Respublike Dagestan. Infekcionnye bolezni: novosti, mnenija, obuchenie. 2020; 4 (35): 46-53. Russian.

4. Chakraborty C, Sharma AR, Sharma G, Bhattacharya M, Lee SS. SARS-CoV-2 causing pneumonia-associated respiratory disorder (COVID-19): diagnostic and proposed therapeutic options. Eur Rev Med Pharmacol Sci. 2020 Apr; 24 (7): 4016-26. DOI: 10.26355/ eurrev_202004_20871. PMID: 32329877.

5. Lauxmann MA, Santucci NE, Autrán-Gómez AM. The SARSCoV-2 Coronavirus and the COVID-19 Outbreak. Int Braz J Urol. 2020 Jul; 46 (suppl.1): 6-18. DOI: 10.1590/S1677-5538. IBJU.2020.S101. PMID: 32549071; PMCID: PMC7719995.

6. Chuchalin AG, Sinopalnikov Al, Kozlov RS, Avdeev SN, Tjurin IE, Rudnov VA, et al. Rossijskoe respiratornoe obshhestvo (RRO). Mezhregional'naja associacija po klinicheskoj mikrobiologii antimikrobnoj himioterapii (MAKMAH). Klinicheskie rekomendacil po diagnostike, lecheniju i profilaktike tjazheloj vnebol'nichnoj pnevmonii u vzroslyh. Pul'monologija. 2014; (4): 13-48. Russian.

7. Welte T, Torres A, Nathwani D. Clinical and economic burden of community-acquired pneumonia among adults in Europe. Thorax. 2010. DOI: 10.1136/thx.2009.129502.

8. Jackson ML, Neuzil KM, Thompson WW, et al. The burden of community-acquired pneumonia in seniors: results of a population-based study. Clin Infect Dis. 2004; 39: 1642-50.

9. File TM Jr, Marrie TJ. Burden of community-acquired pneumonia

in North American adults. Postgrad Med. 2010; 122 (2): 130-41.

10. Ramirez JA, Wiemken TL, Peyrani P, et al. Adults Hospitalized With Pneumonia in the United States: Incidence, Epidemiology, and Mortality. Clin Infect Dis. 2017; 65 (11): 1806-12.

11. American Thoracic Society / Infectious Diseases Society of America. Guidelines for the management of adults with hospitalacquired, ventilator-associated, and healthcare-associated pneumonia. Am J Respir Crit Care Med. 2005; 171: 388-416.

12. Sinopalnikov Al, Kozlov RS, redaktory. Vnebol'nichnye infekcii dyhatel'nyh putej: rukovodstvo dlja vrachej. M.: Prem'er MT, Nash Gorod, 2007; 353 s. Russian.

13. Klimko NN, Vasileva NV. Mikozy legkih. V knige: Chuchalin A. G. Respiratornaja medicina. M.: GJeOTAR-Media, 2007; T. 1, s. 549-576. Russian.

14. Sligl WI, Marrie TJ. Severe Community-Acquired Pneumonia. Crit Care Clin. 2013; 29: 563-601.

15. Saltykova TS, Zhigarlovskiy BA, Briko NI, Vyazovichenko YV. Epidemiological parallels of community-acquired pneumonia, influenza and ARVI in Moscow. Tuberculosis and Lung Diseases. 2020; 98 (3): 6-12. Russian.

16. Oficial'nyj internet-resurs dlja informirovanija naselenija po voprosam koronavirusa (COVID-19). Dostupno po adresu: stopkoronavirus.If (data obrashhenija: 01.09.2020). Russian.

17. Beljakov VD, SemenenkoTA, Shraga MH. Vvedenievjepidemiologiju infekcionnyh i neinfekcionnyh zabolevanii cheloveka. M.: Medicina, 2001; 264 s.

18. Garcia-Vidal C, et al. Incidence of co-infections and superinfections in hospitalized patients with COVID-19: a retrospective cohort study. Clinical Microbiology and Infection. 2021 Jan; 27 (1): 8388. DOI: 10.1016/j.cmi.2020.07.041.

19. Baek Moon Seong, et al. Clinical and radiological findings of adult hospitalized patients with community-acquired pneumonia from SARS-CoV-2 and endemic human coronaviruses. PloS One. 2021; 16 (1): e0245547. DOI: 10.1371/journal.pone.0245547. 


\section{Литература}

1. Gorbalenya AE, Baker SC, et al. Coronaviridae Study Group of the International Committee on Taxonomy of Viruses. The species Severe acute respiratory syndrome-related coronavirus: classifying 2019-nCoV and naming it SARS-CoV-2. Nat Microbiol. 2020; 5: 536-44.

2. Guan WJ, Ni ZY, Hu Y, et. al. Clinical Characteristics of Coronavirus Disease 2019 in China. N Engl J Med. 2020 Apr 30; 382 (18): 1708-20. DOI: 10.1056/NEJMoa2002032. Epub 2020 Feb 28. PMID: 32109013; PMCID: PMC7092819.

3. Асхабова Л. М., Сабиров Л. Ф., Унтилов Г. В., Гаджиева Л. А. COVID-19 в Республике Дагестан. Инфекционные болезни: новости, мнения, обучение. 2020; 4 (35): 46-53.

4. Chakraborty C, Sharma AR, Sharma G, Bhattacharya M, Lee SS. SARS-CoV-2 causing pneumonia-associated respiratory disorder (COVID-19): diagnostic and proposed therapeutic options. Eur Rev Med Pharmacol Sci. 2020 Apr; 24 (7): 4016-26. DOI: 10.26355/eurrev_202004_20871. PMID: 32329877.

5. Lauxmann MA, Santucci NE, Autrán-Gómez AM. The SARSCoV-2 Coronavirus and the COVID-19 Outbreak. Int Braz J Urol. 2020 Jul; 46 (suppl.1): 6-18. DOl: 10.1590/S1677-5538. IBJU.2020.S101. PMID: 32549071; PMCID: PMC7719995.

6. Чучалин А. Г., Синопальников А. И., Козлов Р. С., Авдеев С. Н., Тюрин И. Е., Руднов В. А. и др. Российское респираторное общество (РРО). Межрегиональная ассоциация по клинической микробиологии и антимикробной химиотерапии (MAKMAX). Клинические рекомендации по диагностике, лечению и профилактике тяжелой внебольничной пневмонии у взрослых. Пульмонология. 2014; (4): 13-48.

7. Welte T, Torres A, Nathwani D. Clinical and economic burden of community-acquired pneumonia among adults in Europe. Thorax. 2010. DOI: 10.1136/thx.2009.129502.

8. Jackson ML, Neuzil KM, Thompson WW, et al. The burden of community-acquired pneumonia in seniors: results of a population-based study. Clin Infect Dis. 2004; 39: 1642-50.
9. File TM Jr, Marrie TJ. Burden of community-acquired pneumonia in North American adults. Postgrad Med. 2010; 122 (2): 130-41.

10. Ramirez JA, Wiemken TL, Peyrani P, et al. Adults Hospitalized With Pneumonia in the United States: Incidence, Epidemiology, and Mortality. Clin Infect Dis. 2017; 65 (11): 1806-12.

11. American Thoracic Society / Infectious Diseases Society of America. Guidelines for the management of adults with hospitalacquired, ventilator-associated, and healthcare-associated pneumonia. Am J Respir Crit Care Med. 2005; 171: 388-416.

12. Синопальников А. И., Козлов Р. С., редакторы. Внебольничные инфекции дыхательных путей: руководство для врачей. М.: Премьер МТ, Наш Город, 2007; 353 с.

13. Климко Н. Н., Васильева Н. В. Микозы легких. В книге: Чучалин А. Г. Респираторная медицина. М.: ГЭОТАР-Медиа, 2007; T. 1, c. 549-576.

14. Sligl WI, Marrie TJ. Severe Community-Acquired Pneumonia. Crit Care Clin. 2013; 29: 563-601.

15. Салтыкова Т. С., Жигарловский Б. А., Брико Н. И., Вязовиченко Ю. В. Эпидемиологические параллели внебольничных пневмоний, гриппа и ОРВИ в г. Москве. Туберкулез и болезни легких. 2020; 98 (3): 6-12.

16. Официальный интернет-ресурс для информирования населения по вопросам коронавируса (COVID-19). Доступно по адресу: стопкоронавирус.рф (дата обращения: 01.09.2020).

17. Беляков В. Д., Семененко Т. А., Шрага М. Х. Введение в эпидемиологию инфекционных и неинфекционных заболеваний человека. М.: Медицина, 2001; 264 с.

18. Garcia-Vidal C, et al. Incidence of co-infections and superinfections in hospitalized patients with COVID-19: a retrospective cohort study. Clinical Microbiology and Infection. 2021 Jan; 27 (1): 8388. DOI: 10.1016/j.cmi.2020.07.041

19. Baek Moon Seong, et al. Clinical and radiological findings of adult hospitalized patients with community-acquired pneumonia from SARS-CoV-2 and endemic human coronaviruses. PloS One. 2021; 16 (1): e0245547. DOI: 10.1371/journal.pone.0245547. 